1953 and brings the total for the year to 190 grants worth $1,810,200$ dollars. The fields covered are astronomy, chemistry, developmental biology, earth sciences, engineering, genetic biology, mathematics, molecular biology, physics, psychobiology, regulatory biology, research education in the sciences, scientific information, studies in science, and systematic biology. The grants range from six months to three years, with an average length of $1 \cdot 6$ years.

\section{Subject Index of British Patent Specifications}

BECAUSE of war-time difficulties, the printing of subject indexes to British patent specifications since 1939 (Nos. 500,001 onwards) had fallen badly into arrears. Good progress has recently been made in reducing these arrears, but their complete elimination is unlikely to be achieved in less than two years. Meanwhile, searches continue to be difficult and costly. The Patent Office has now permitted Aslib to make 35-mm. microfilm copies of the Patent Office's own Press Mark Indexes and to make them universally available. The Press Mark Index - which will be in most cases the only subject index available in respect of 1939-53 (April 30)-is a fourteen-year cumulative list of the 271 patent classes showing the numbers of the patents in each and their allocation to sub-classes. Microfilm copies of the Index (nearly 8,000 pages) are now available, price $£ 1010 s$, from the Director, Aslib, 4 Palace Gate, London, W.S.

\section{Eleventh Conference of the International Federation of University Women}

THE eleventh conference of the International Federation of University Women will be held in London at Bedford College during August 6-13, with the British Federation of University Women acting as the host body. More than five hundred representatives from the thirty-one countries affiliated to the International Federation have arranged to attend. A large part of the conference programme will be devoted to business meetings at which the affairs of the International Federation will be discussed and arranged. The Federation is responsible for the award of international research fellowships, seventyeight having been awarded since its foundation to scholars of twenty-four countries ; for furthering the interests of professional women ; for the development of cultural relations between members of the Federation in different countries; and for helping displaced university women, of whom there are still large numbers, especially among the elderly. In addition to the business meetings, it is the custom of these conferences to choose a special subject to be considered at a number of public lectures and group discussions; the theme this year is "Human Values in the Technical World", and the conference will open with an inaugural lecture by Sir Henry Self on "London Town", which will deal with the part London has played as a focal point of technical development within the wider field of scientific and humanistic thought. The enrolment fee for the conference is £3 and application forms can be obtained from the Conference Secretary, I.F.U.W. Headquarters, 1 Sedding Street, Sloane Square, London, S.W.1.

\section{Toronto Meteorological Conference}

Tre American Meteorological Society and the Royal Meteorological Societies are to hold a joint meeting in Toronto during September 9-15; the Canadian Branch of the Royal Meteorological Society will be responsible for the local arrangements. The meeting has been made possible by the generosity of the Munitalp Foundation in America, which has made a substantial grant available to both Societies with the view of promoting co-operation and goodwill between them. The programme includes symposia and discussion on the following subjects : ozone and the high atmosphere; cloud physics and induced precipitation; modern cyclone theory; arctic meteorology; radiation; climatic change; microclimatology ; high-level forecasting; general circulation. This will be the first occasion upon which the two Societies have arranged a joint meeting.

\section{Announcements}

Mr. L. G. Melville has been appointed vicechancellor of the Australian National University, Canberra, in succession to Sir Douglas Copland, who has recently assumed office as High Commissioner for Australia in Ottawa. Mr. Melville is Australian Executive Director of the International Bank for Reconstruction and Development and the International Monetary Fund in Washington; he is a distinguished economist, who was formerly professor of economics in the University of Adelaide.

Dr. Carey Croners has been appointed provost and Harry Carothers Wiess professor of geology in the Rice Institute, Houston, Texas. Dr. Croneis, who will take up his new office in January, was born in Bucyrus, Ohio, in 1901, and holds degrees of Denison, Kansas and Harvard Universities. During 1928-44 he was a member of the geology faculty of the University of Chicago and since 1944 has been president of Beloit College.

THE following appointments in the University of London have been announced: Dr. W. St. C. Symmers, senior lecturer in the University of Birmingham, to the University chair of morbid anatomy tenable at Charing Cross Hospital Medical School; Dr. J. H. F. Brotherston, senior lecturer in public health at the London School of Hygiene and Tropical Medicine, to the University readership in public health tenable at that School.

THE following appointments in the University of Nottingham have been announced: Dr. Rodney Hill, Research Fellow in theoretical mechanics in the University of Bristol, to the newly established chair of applied mathematics from October 1; Dr. K. W. H. Stevens, Research Fellow in theoretical physics in the University of Oxford, to be reader in theoretical physies from October 1.

Ramsay Memorial Fellowships for research in chemistry have been awarded for 1953-54 to the following : Mr. G. T. Rogers, a British Fellowship of $£ 500$ a year in the University of Cambridge; Mr. B. I. Parsons, a Canadian Fellowship in the University of Oxford; Mr. Santos Amer, a Spanish Fellowship in the University of Bristol; Mr. Gines Guzman, a Spanish Fellowship in the University of Oxford; Mr. R. H. Doremus, a United States Fellowship in the University of Cambridge. British Fellowships held by Dr. G. H. R. Summers (Cambridge) and Dr. R. F. Webb (Cambridge) have been renewed for 1953-54.

WoRk in progress at the Chemical Research Laboratory, Teddington, will be demonstrated at a series of open days during September 22-25. Applications from industrial firms for invitations to the sessions should be sent to the Director before August 31 . 